\title{
An application of the ground laser scanning to recognise terrain surface deformation over a shallowly located underground excavation
}

\author{
Elżbieta Pilecka ${ }^{1, *}$, and Dariusz Szwarkowski ${ }^{1}$ \\ ${ }^{1}$ Politechnika Krakowska, Instytut Mechaniki Budowli, 31-155 Kraków, Poland
}

\begin{abstract}
In the Upper Silesian Coal Basin area, there are post-mining sites of shallow exploitation of metal ores and hard coal deposits that reveal discontinuous deformations. Most often, these areas are heavily urbanised and the appearing deformations may be dangerous to the existing building infrastructure. The work, described in this article, presents the results of the research, which aimed to rate the usefulness of laser scanning to recognize discontinuous deformations on surface areas located over shallow mining excavations. Two laser scanning measurements were taken over the course of a few months. The surface area images were compared to identify changes in its deformation, especially those areas located above mining excavations. The tests carried out by the laser scanning method showed that some of the identified discontinuous deformations could have been connected to the shallowly located mining excavations.
\end{abstract}

\section{Introduction}

Shallowly located mining excavations, which lose their stability over time, may have an influence on surface area deformations [1-4]. Most often, different kinds of discontinuous deformations appear on the surface area: pit-holes, sinkholes, synclines, etc. [3,4] (Fig.1). In the Upper Silesian Coal Basin (USCB), these deformations pose a considerable risk to various building objects, including road infrastructure [5-7].

The effects of sinkhole processes that develop in mining terrains, are most often identified by different geophysical methods [8-13]. In the geological and mining conditions of USCB, the most frequently are used: gravimetric, seismic, electric, and georadar methods, among them borehole georadar [13].

The basic information on terrain surface deformations above mining areas can be obtained using a classic geodetic method [14]. More and more frequently, remote sensing methods are also used - satellite, or drone $[15,16]$. In some zones of surface deformation, ground laser scanning can also be used [17-21]. The advantages of the ground laser scanner are: uncomplicated measurement, time independence, and sufficiently accurate results [18]. Laser scanning has already proven to be useful in the reclamation of post-mining areas [19, $21,22]$.

\footnotetext{
*Corresponding author: epilecka@pk.edu.pl
} 


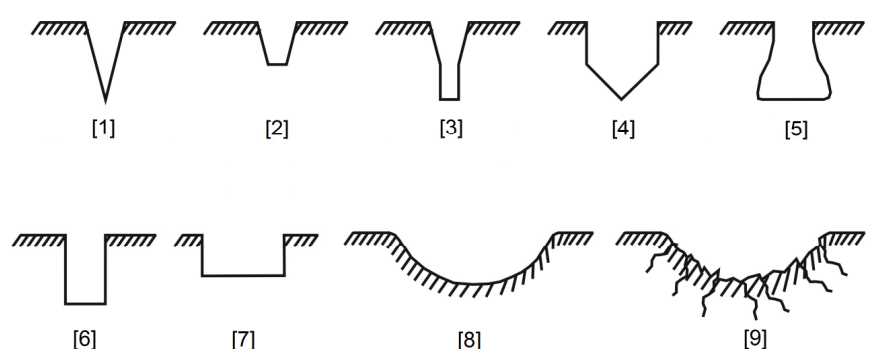

Fig.1. Kinds of discontinuous deformations of the terrain surface in view of geometries in the vertical section observed in the area of Upper Silesia Coal Basin [2,4].

Description: [1] - conical sinkhole, [2] - truncated sinkhole, [3] - conical-cylindrical sinkhole, [4] cylindrical - conical sinkhole, [5] - bell sinkhole, [6] - cylindrical sinkhole, [7] - cuboid sinkhole, [8] - continuous syncline, [9] - discontinuous syncline.

The basic information on terrain surface deformations above mining areas can be obtained using a classic geodetic method [14]. More and more frequently, remote sensing methods are also used - satellite, or drone $[15,16]$. In some zones of surface deformation, ground laser scanning can also be used [17-21]. The advantages of the ground laser scanner are: uncomplicated measurement, time independence, and sufficiently accurate results [18]. Laser scanning has already proven to be useful in the reclamation of post-mining areas [19, $21,22]$.

The work in this article presents the results of ground laser scanning in the post-mining, heavily urbanized area in USCB (Fig.2). The aim of the performed tests was to evaluate the usefulness of laser scanning to recognize discontinuous deformations on the surface, for areas located over shallow mining excavations at the depth of about $32 \mathrm{~m}$. Two laser scanning measurements were taken over a few months. The surface area images were then compared to identify changes in deformation, especially those over mining excavations.

\section{Research area characteristics}

The research area is located in the southern part of Poland, in the USCB area (Fig.2), where intensive mining has taken place since the early Middle Ages. This area is mainly connected with shallow exploitation of zinc and lead ores and, to a lesser extent, iron and silver ores, and shallow and deep exploitation of hard coal deposits [7, 9, 10]. This research area is an example of a place that is presumably endangered by discontinuous deformations, due to the shallow exploitation of hard coal deposits.

Pleistocene fluvioglacial formations occur in depths up to $30.5 \mathrm{~m}$ in the studied area, in the form of varigrained sands, loamy sands, and sandy clays, as well as compact sandy clays with limestone crumbs. At deeper depths, there are carboniferous formations, in which mining excavations were made. Carboniferous formations in the top are represented by immature residual soil in the form of residual clay soil with shale interlayers, mudstones, sandstones, and hard coal inserts and deposits.

In the research area, at the depth of about $32 \mathrm{~m}$, there are two main galleries in the direction close to a parallel and perpendicular to the beddings of the Carboniferous formations, excavated in the $19^{\text {th }}$ and $20^{\text {th }}$ century. The main galleries were crossed by roadways excavated in different coal seams. Additionally, the excavations were crossed with faults of throws of up to several meters (Fig.2). Due to such an arrangement of the excavations, a weak zones in rock mass were created, mainly in the area of excavation junctions, which presumably can create conditions for the development of sinkhole processes. 
The surface of the studied area is a city park with big trees and shrubs. In the neighbourhood, there are also buildings, a pavement for pedestrians, and asphalt roads.

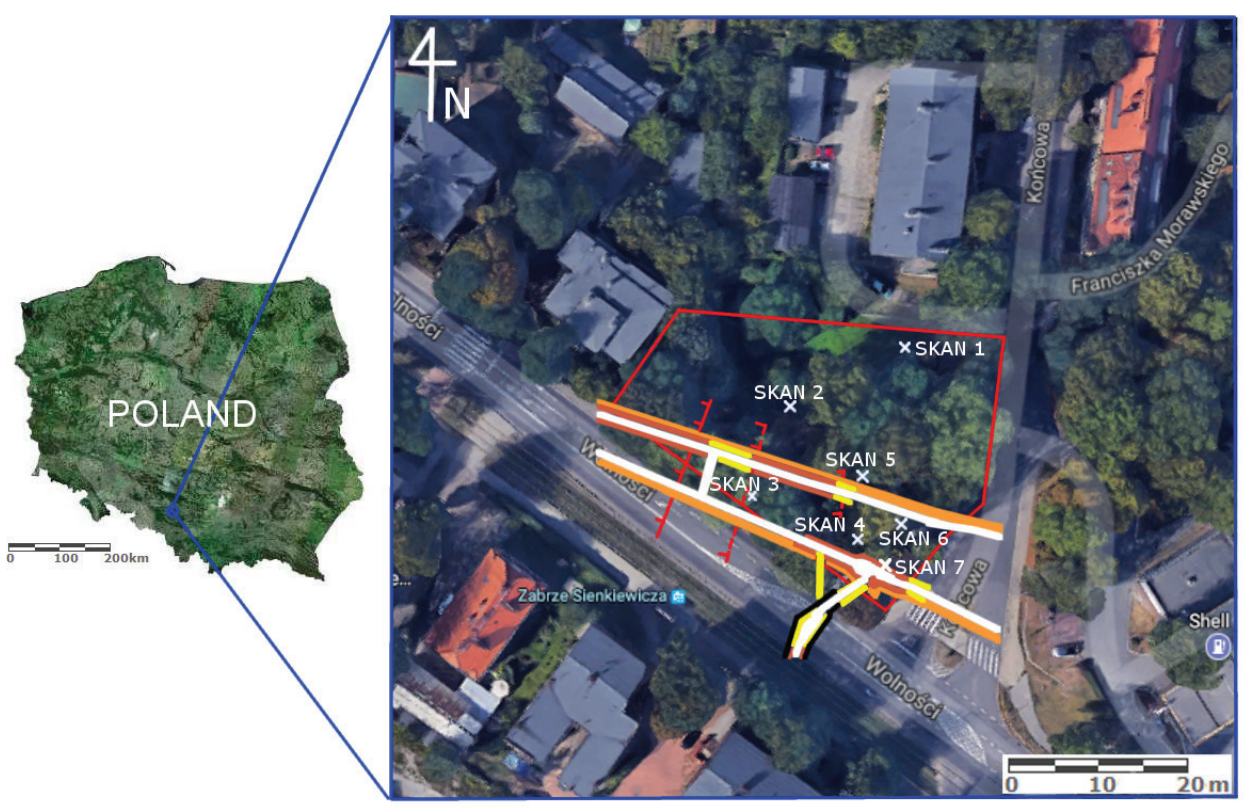

Fig. 2. Location of test stands, on the orthophotomap of the analysed area with marked excavations [10].

\section{Methodology}

The aim of the ground laser scanning is the most faithful mapping of the terrain surface. The measurements are based on sending and recording a laser beam, which is reflected from different objects [22] (Fig.3). The reflected signals, registered by the scanner, are converted into an electric signal and are then subjected to further digital processing.

The vertical lines on the signal envelope (Fig. 3) correspond to the sampling time. According to the waveform analysis and when it reached the receiver, calculations were made for the signals reflected in $\mathrm{t} 1, \mathrm{t} 2, \ldots, \mathrm{t} 4$ times, for the subsequent reflecting objects. For the known light beam velocity and its run time from the emitter to the receiver, the distance between the scanner and the reflecting body is determined.

The wave emitted is characterised by high frequency - for Riegl VZ-4000 scanner $\mathrm{f}$ $=122 \mathrm{kHz}$ [22]. It allows for the scanning of several dozen to hundreds of thousands of measurement points in each measurement second. The obtained mapping of the scanned area is most often characterised by a dozen or more million points in the Cartesian space $(\mathrm{x}, \mathrm{y}, \mathrm{z})$.

The data set, in the form of a point cloud, creates an image of the scanned space. An example of such an image is shown in Fig.3. It illustrates the research area described in this work. The measured space data was then archived for further processing. The factors influencing measurement quality deterioration include precipitations resulting in disturbances in the cloud of points. Precipitation causes the "noisiness" of the resulting image.

The difficulty in the laser recording processes is the vast amount of data. Therefore, the most essential fragments of the area are chosen for the analysis. The result of the ground laser scanner measurement is the final scan, formed as a result of combining data from 
various measurement stands (Fig.4). When processing the measurement data, trees and shrubs can create different difficulties. The registration of the changing position of leaves and branches during measurement increases the time of data processing. The removal of unwanted objects (particularly trees, shrubs, fences, etc.) is necessary and influences the simplicity of the scanned relief of the area.

The results presented in this work were obtained using a Riegl VZ-400 scanner. The maximum scan range for this scanner was 400 to $500 \mathrm{~m}$ [22], with an accuracy measurement of $5 \mathrm{~mm}$. Measurements were taken in 'long scan mode', which has a maximum resolution. Scans from particular measurement stands were then linked to the reference scan in RiSCAN PRO.

The measurement by the ground laser scanner was carried out in two series on February 23, 2017 and June 1, 2017, covering the duration of spring melt. Measurements were made on seven stands which were positioned as shown in figure 2 , marked by blue crosses. The measurement from February 23 made it possible to minimize the negative effects of the vegetation.
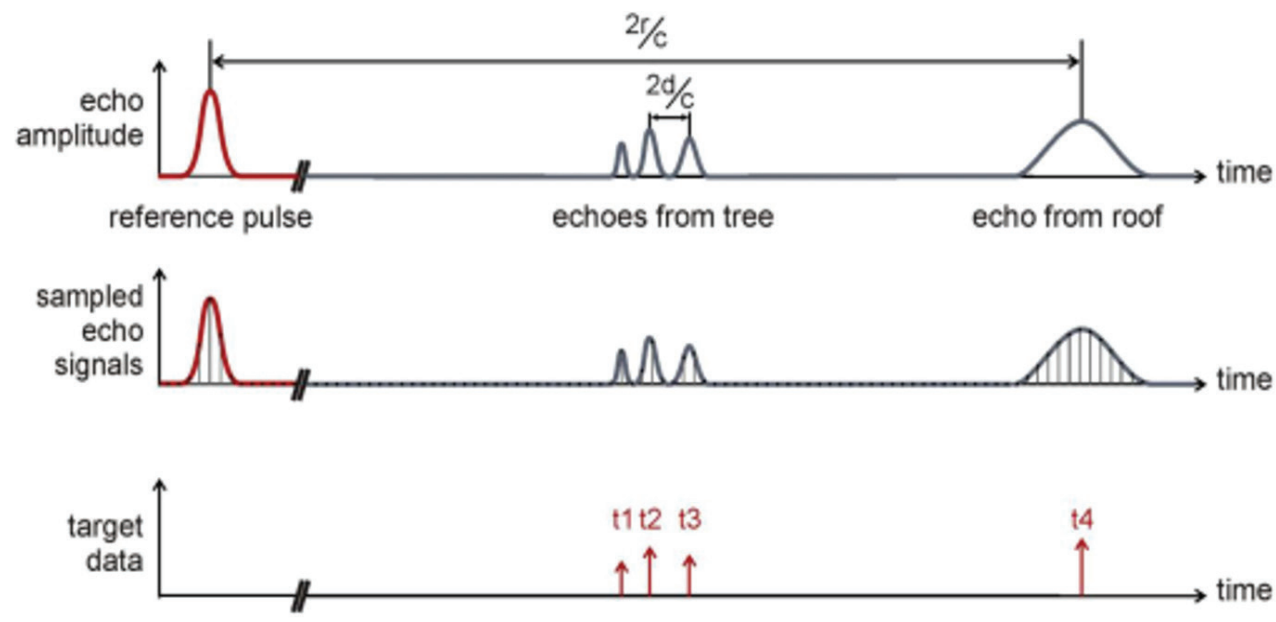

Fig. 3. Diagram of determining the position of objects in the measurement with a laser scanner. Description in text [23].

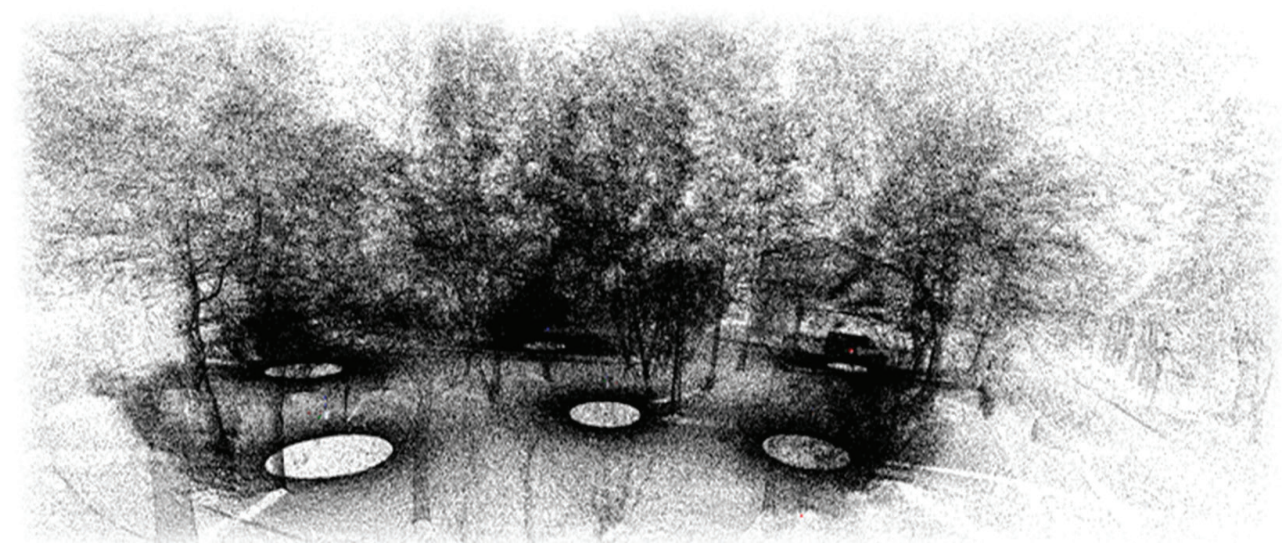

Fig. 4. An example of an image formed as a result of connecting scans from measurement stands in the research area. 


\section{Results and analysis}

\subsection{Measurement I}

Laser scanning measurements were taken on February 23, 2017 which made it possible to develop a model of the surface area presented in Fig. 5. On the terrain surface model, mining excavations are denoted.

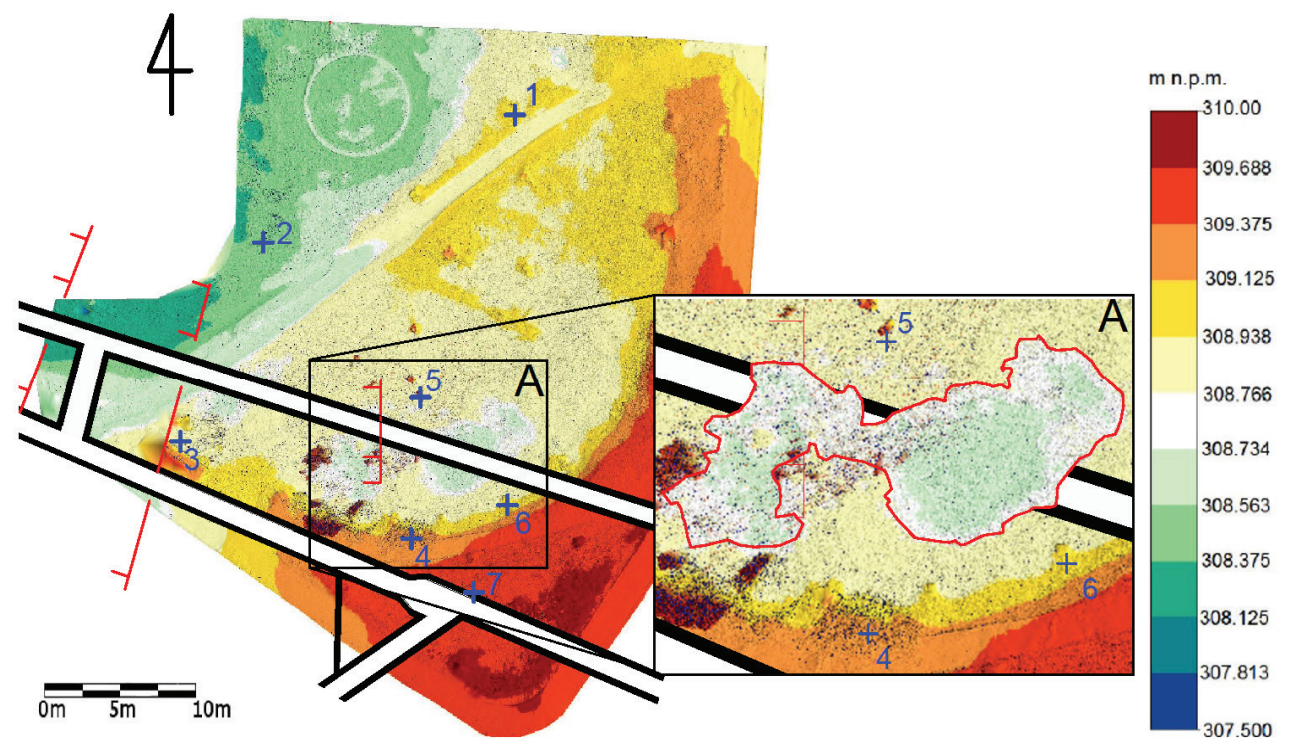

Fig. 5. The terrain surface model obtained from laser scanning on February 23, 2017.

The study area is characterised by a relatively flat surface of terrain. The measured elevations ranged from 307,500 to $309,688 \mathrm{~m}$ a.s. 1 . From the terrain surface image, it is evident that there are different zones of land subsidence of various sizes. The largest subsidence zone, limited by a blue line and marked as A in Fig. 5, is located over northern gallery. The zone is about $15 \mathrm{~m}$ long and $5 \mathrm{~m}$ wide. The local maximum land elevation in zone A differ by as much as $20 \mathrm{~cm}$.

In zone A, from the south-east, there is also a distorted fragment between the area with the pavement for pedestrians and the neighbouring road, however the causes of such a deformation can be complex. Some of the subsidence zones in the entire studied area are beyond the possible impact of the excavations on the area surface. On the other hand, there is no anomalous subsidence visible in the north part of the studied area where the closest building is located.

\subsection{Measurement II}

Laser scanning measurements carried out on June 1, 2017 made it possible to develop a surface area model presented in Fig.6. The results of these measurements were very similar to the ones taken on February 23, 2017. Taking into consideration the results of both measurements, it should be stressed that local subsidence in the research area occurs in many places, not only on the mining sites. The largest of them and of the biggest local subsidence A', significantly exceeding the measurement error are marked over area between both galleries (Fig. 6). 


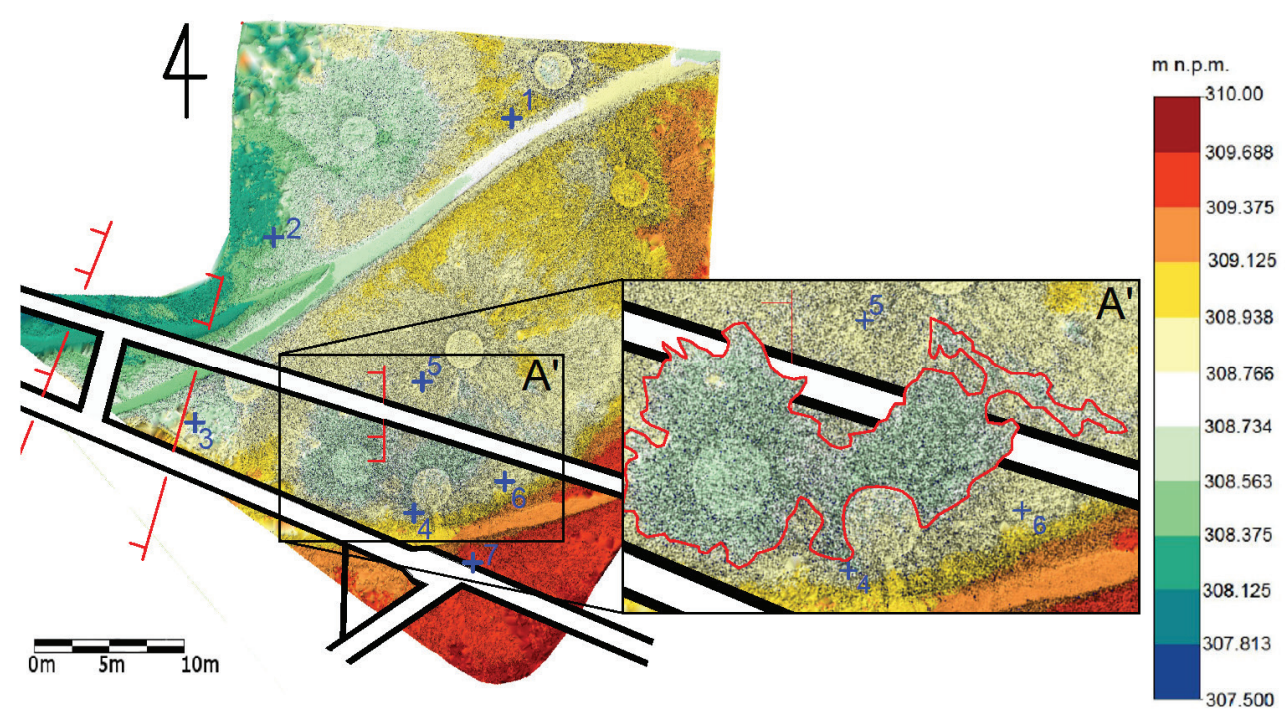

Fig. 6. Terrain surface model from laser scanning from June 1, 2017.

\subsection{Differential model}

The developed models of laser scanning in measurements I and II made it possible to develop a differential model of the studied area (Fig.7). The calculated differences in the ordinate values of the area surface are up to $-2 \mathrm{~cm}$. The differential zone, marked B1 in figure 7, occurs between the galleries, in the vicinity of the junction of south gallery with breakthrough. On the other hand, the B2 differential zone is north of the marked galleries, and from the available data, it is difficult to explain its origin.

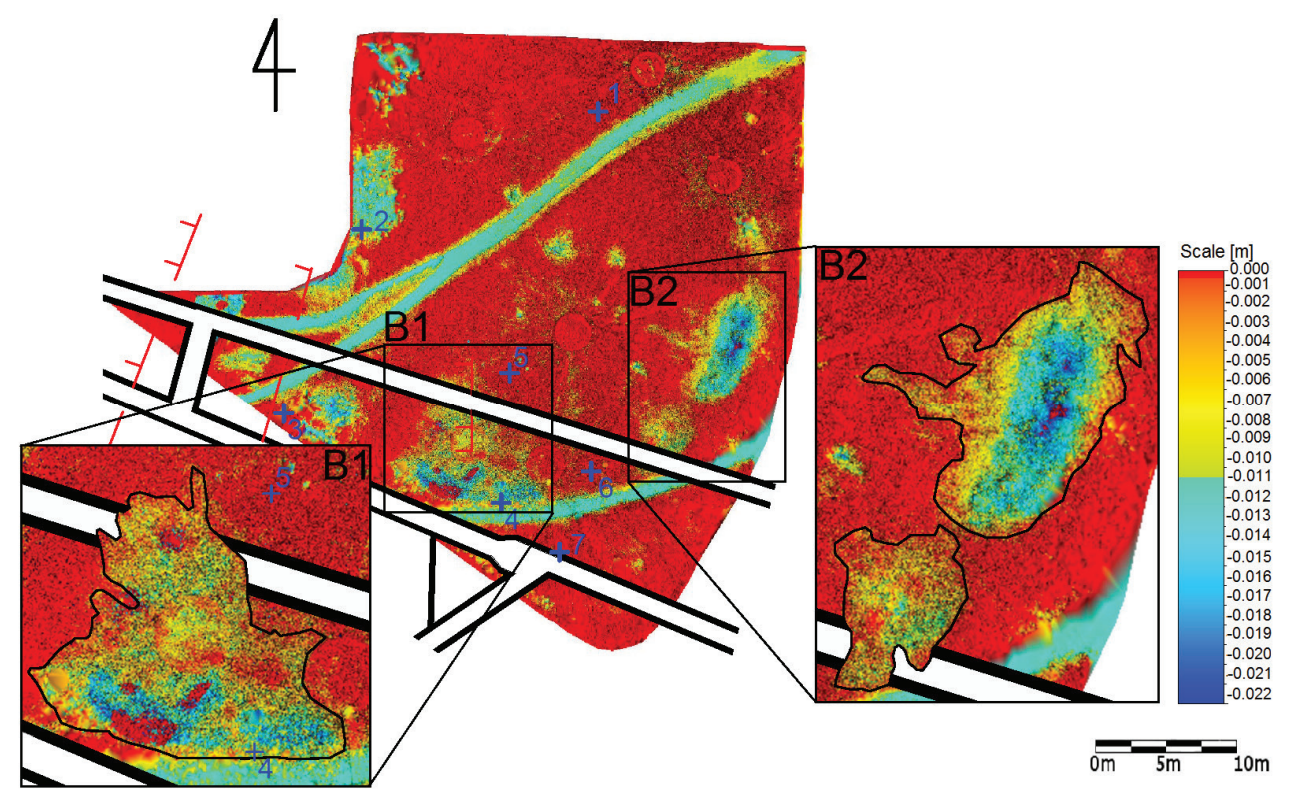

Fig. 7. Differential model of two laser scanning measurements on February 23, 2017 and June 1, 2017. 
The results of differential calculations show that the biggest subsidence values are associated with A/A' zone in figures 5 and 6 . This zone is located between the galleries, north of the junction of the south gallery and the breakthrough. The observed subsidence can have many causes, however what should not be excluded is the subsidence process developing in the ground over shallowly located, historical mining excavations. A small range of the subsidence zone indicates for a local phenomenon.

\section{Summary}

The work presents the results of laser scanning in the post-mining, heavily urbanised area of USCB, in order to evaluate the usefulness of the method for recognising discontinuous deformations on the terrain surface over shallowly located, historic mining excavations.

The results from two measurements taken over the course of several months proved the existence of local area subsidence zones, of values significantly exceeding that of the measurement error. Some of them occurred over the mining excavations. In zone B1, differential subsidence reached about $2 \mathrm{~cm}$ in a period of three months. Such a result may also be the effect of the defrosting of the ground surface, since the first measurements were made in February.

On the other hand, the differential values of the subsidence in B2 zone may have different causes, and on the basis of available data, it is difficult to explain this anomaly. However, the deformations found, are rather small and cannot be dangerous for the nearby buildings.

In order to examine the reasons of local subsidence in more detail, geophysical measurements properly chosen for the geological and mining conditions should be made. In the case of a geophysical anomaly, an inspection borehole would be required to verify this measurement.

The obtained results prove the usefulness of laser scanning to recognize discontinuous deformations on the terrain surface over shallowly located mining excavations.

This laser scanning method provides initial recognition for the probable occurrence of discontinuous deformations. These measurements are of great significance, especially in urban areas where other measurements are disrupted in different ways. They can also be used to assess the causes of damage to buildings, associated, for example, with mining activity.

\section{References}

1. B.N. Whittaker, D.J. Reddish, Subsidence: occurrence, prediction and control (Elsevier, Amsterdam 1989)

2. M. Chudek, Geomechanika z podstawami ochrony środowiska górniczego $i$ powierzchni terenu (Wyd. Politechniki Śl., Gliwice 2002)

3. A. Goszcz, Powstawanie zapadlisk $i$ innych deformacji nieciagtych powierzchni na obszarach ptytkiej eksploatacji górniczej, Mat. Konf.: Szkoła Eksploatacji Podziemnej '96, 119-137 (CPPGSMiE PAN w Krakowie, Szczyrk 1996)

4. E. Popiołek, Z. Pilecki (eds.) Ocena przydatności do zabudowy terenów zagrożonych deformacjami nieciagtymi za pomoca metod geofizycznych (Wyd. IGSMiE PAN, Kraków 2005)

5. Z. Pilecki, Methodology for A-1 motorway basement treatment effectiveness improvement by means of geophysical methods in the areas of metal ores shallow mining threatened with the sinkhole occurrence in the Upper Silesia, Gospod. Surowcami Min. 3, 25, 319-331 (2009) 
6. A. Miłkowski, Z. Pilecki, K. Kłosek, M. Tondera, Autostrada Al zaprojektowana na ,dziurawym” podłożu, Cz. 1, Magazyn Autostrady: budownictwo drogowomostowe 3, 104-112 (2010)

7. Z. Pilecki, A. Kotyrba, Problematyka rozpoznania deformacji nieciagtych dla potrzeb projektowania konstrukcji drogowych na terenie ptytkiej eksploatacji rud metali, Prace Naukowe GIG III, 379-392 (2007)

8. H. Marcak, Z. Pilecki, Some Geophysical and Geomechanical Remarks on Recognition Sinkhole Processes in Post-Mining Areas, Proc. $12^{\text {th }}$ European Meeting of Environmental and Engineering Geophysics, EAGE (Helsinki, Finland, 4 - 6 Sept. 2006)

9. Z. Pilecki, E. Popiołek, Wpływ eksploatacji rud na zagrożenie powierzchni deformacjami nieciagtymi $i$ jego badanie za pomoca metod geofizycznych, Studia, Rozprawy, Monografie 84, (Wyd. IGSMiE PAN, Kraków 2000)

10. Z. Pilecki, E. Pilecka, J. Pszonka, J. Stanisz, J. Morman, Zagrożenia deformacjami nieciagłymi na obszarze górniczym Jaworzno III (Wyd. IGSMiE PAN, Kraków 2012)

11. Z. Fajklewicz, Geophys. Prospect. 6, 34, 1233-1254 (1986) doi: 10.111/j.13652478.1986.tb00526.x

12. Z. Pilecki, The role of geophysical methods in the estimation of sinkhole threat in the post-mining areas of shallow exploitation in the Upper Silesian Coal Basin, Poland, Gospod. Surowcami Min. 3/1, 24, 27-40 (2008)

13. T. Łątka, Pilecki Z. Metoda oceny stopnia spękania ośrodka skalnego za pomoca georadaru otworowego, Studia, Rozprawy, Monografie 200 (Wyd. IGSMiE PAN, Kraków 2017)

14. E. Popiołek, Ochrona Terenów Górniczych (Wydaw. AGH, Kraków 2009)

15. M. Kniotek, A. Leśniak, Analiza zwiazku sejsmiczności indukowanej z osiadaniami terenu na obszarze GZW $z$ wykorzystaniem satelitarnych zobrazowań SAR, Budownictwo Górnicze i Tunelowe 4; 21, 36-41 (2015)

16. M. Graniczny, A. Piatkowska, E. Pilecka, An applictaion of the remote sensing technology to the high energy seismic activity on the example of the Upper Silesian Coal Basin, Polish Geological Institute Special Papers 20, $92-98$ (2005)

17. E. Pilecka, Teledetekcja jako metoda analizy ruchów masowych, Zeszyty Naukowe Bulletin of the Mineral and Energy Economy Research Institute of the Polish Academy of Sciences 84, 103-115 (2013)

18. Z. Muszyński, W. Milczarek, Modelowanie przemieszczeń pionowych na podstawie danych z naziemnego skanera laserowego. Geoinformacja jako metoda ochrony przed geozagrożeniami, 42-63 (Warszawa 2014)

19. E. Pilecka, D. Szwarkowski, Wykorzystanie skanera laserowego RIEGL VZ-400 do badania deformacji na terenach górniczych GZW, Budownictwo Górnicze i Tunelowe 4, 21 (2015)

20. P. Gruchlik, Naziemne skanowanie laserowe 3D, doświadczenia $i$ perspektywy, Przegląd Górniczy 5, 71, 20-24 (2015)

21. M. Bazarnik, Możliwości aplikacyjne techniki naziemnego skanowania laserowego $3 D$ $w$ rekultywacji terenów górniczych, Zeszyty Naukowe - Bulletin of the Mineral and Energy Economy Research Institute of the Polish Academy of Sciences 94, 149-160 (2016)

22. Riegl LMS, Oprogramowanie Systemowe i Przetwarzania Danych RiSCAN PRO dla skanerów laserowych 3D firmy RIEGL LMS, (Austria 2009) 